\title{
NEVOIA DE OPTIMIZARE A CONSUMULUI DE SPAȚIU URBAN Analiza densității urbane și a modelului de urbanizare în regiunea București-llfov, România/
}

\author{
THE NEED FOR OPTIMIZING URBAN SPACE \\ The Analysis of Urban Density and Urbanization Patterns in the Bucharest - Ilfov \\ Region, Romania \\ Iulia Simona FLOROIU, drd. arh. urb./ PhD. stud. arch. urb. \\ arhitect.iulia@gmail.com \\ Radu-Matei COCHECl, asist. dr. urb./ assist. PhD. urb. \\ matei.cocheci@uauim.ro
}

Universitatea de Arhitectură şi Urbanism „Ion Mincu”, Bucureşti, RO/

„Ion Mincu” University of Architecture and Urbanism, Bucharest, RO

\section{Rezumat}

Scopul lucrării este încurajarea dialogului privind densificarea urbană în contextul actual european, evidențiind diferențele în abordarea reurbanizării în Europa de Vest și țările post-comuniste. Fără a neglija concepte de importantă actualitate, precum necesitatea planificării reziliente, adaptabilitatea la schimbările climatice ori procesul de gentrificare asociat modelelor de reurbanizare, lucrarea se concentrează pe definirea și măsurarea densificării urbane ca pași premergători planificării rezidențiale sustenabile în orașele europene.

Urmărind o analiză a procesului de densificare urbană într-o serie de arii metropolitane europene și relația acestuia cu oferta eficientă de servicii

\begin{abstract}
The aim of this paper is to discuss the concept of urban density in Europe's present urbanization context, highlighting the existing differences in urbanization patterns between Western European and post-communist countries. Without neglecting important debates such as the need to plan for climate change or the gentrification processes associated with re-urbanization patterns, the paper focuses on defining and measuring urban density as a pre-requisite for sustainable housing planning in European cities.

Following an analysis of urban density patterns across the European Union and its relationship with the efficient supply of public services for residential
\end{abstract}


publice pentru zonele rezidențiale, lucrarea evidențiază tendințele de evoluție a locuirii în dinamica centru-periferie. Sunt surprinse, aici, diferențe între modelul actual de urbanizare din Europa de Vest (unde ariile metropolitane sunt întro fază de re-urbanizare) cu ceea ce se întâmplă în țările post-comuniste, unde asistăm, după 1990, la un important proces de suburbanizare. Bucureștiul și răspândiții săi sateliți urbani ilustrează elocvent acestă ruptură, fiind într-un proces accelerat de suburbanizare.

Aria metropolitană a Bucureștiului ultimelor două decenii a fost caracterizată de o dezvoltare profund haotică a zonelor suburbane, determinată de neajunsuri economice și legislative - o constantă în majoritatea cazurilor țărilor post-comuniste din Europa Centrală și de Est. Deși densitatea populației din perimetrul urban este în continuă scădere încă din anii 1990, densitatea țesutului urban a crescut în mod semnificativ în ultimul deceniu. Evoluția a fost alimentată de marile proiecte de dezvoltare imobiliară.

În contextul actualizării Planului Urbanistic General al Muncipiului București și a Planului de Amenajare a Teritoriului Județean Ilfov, lucrarea pledează pentru reorientarea direcției de dezvoltare, de la suburbanizare la reurbanizare, posibilă prin încurajarea restructurării țesutului urban abandonat, subutilizat.

\section{Cuvinte cheie/ Keywords}

suburbanizare, țări post-comuniste, densitate urbană, restructurare urbană/

suburbanization, post-communist countries, urban density, urban restructuring areas, the paper relates centre - suburbia population growth trends. The differences between the actual urbanization patterns in Western Europe (where metropolitan areas have entered a reurbanization phase) and the important suburbanization process occurring after 1990 in Post-Communist countries are thus highlighted. Undergoing significant suburbanization processes, this is very well illustrated by the case of Bucharest and its widespread urban satellites.

The Bucharest metropolitan region has been characterized in the last two decades by a chaotic suburban development determined by legislative and economic factors similar to the majority of postcommunist countries in Central and Eastern Europe. While the population density in the city has continuously declined since the 1990s, the builtarea density has seen a significant rise in the last decade, triggered by large-scale real-estate developments.

With two major plans for the metropolitan region, the normative General Urban Plan of the City of Bucharest and the strategic-oriented County Plan of Ilfov, currently being updated, the paper argues that a re-orientation from suburbanization towards reurbanization is possible only by encouraging the restructuring of derelict inner-areas with levels of urban density that allow the efficient provision of basic public services.

\footnotetext{
suburbanization, post-communist countries, urban density, urban restructuring
} 


\section{Introducere - densitate urbană și modele de urbanizare}

Importanța densității în mediul urban este un subiect de mare interes pentru urbaniști în ultimele decenii, în special cu modelele de urbanizare apărute după 1945. Cu toate acestea, definirea clară a densității s-a dovedit a fi o sarcină dificilă, întrucât măsurarea densității construite (număr de locuințe / hectar, Coeficient de Utilizare a Terenului, Procent de Ocupare a Terenului), a densității ocupării (legate de analiza locuirii - mp suprafață locuibilă / persoană) și a densității populației (număr de locuitori / hectar) sunt toate importante în planificarea spațială (Ekurhuleni Metropolitan Municipality 2005). Din punct de vedere economic, densitatea poate fi analizată prin prisma ofertei (cazul densităților impuse de reglementările urbanistice) sau ca rezultat al cererii - populația care trăiește, de fapt, în zonele rezidențiale (Whitehead 2012).

Scopul acestui articol este explicarea importanței densităților urbane ridicate în asigurarea unei planificări sustenabile a zonelor rezidențiale din orașele europene. Discuția despre densitatea urbană va fi focalizată pe procesele de urbanizare din Europa, în special în relație cu diferențele observate în faza de urbanizare a zonelor metropolitane, între țările post-comuniste și cele din vestul Europei.

În Death and Life of Great American Cities, Jane Jacobs subliniază importanța densităților mari ale populației pentru orașele americane, făcând în același timp o distincție clară între densitatea ridicată - definită ca număr de locuitori / hectar - și supra-popularea - exprimată în număr de persoane

\section{Introduction - urban density and urbanization patterns}

The importance of density in an urban environment is a topic which has sparked significant interest from urban planners in the last decades, especially related to the urbanization patterns witnessed after 1945. However, clearly defining density has proven to be a more difficult task, as the measurement of building density (dwelling units / hectare, Floor Area Ratio, Coverage), occupancy density (related to housing analysis - floor space rate or sqm / person) and population density (people / hectare) all play important roles in spatial planning (Ekurhuleni Metropolitan Municipality 2005). From an economic viewpoint, density can be analysed from the supply side (the case of required planning densities imposed by regulations) or as an outcome of demand - the actual population living in residential areas (Whitehead 2012).

The aim of this paper is to explain the importance of higher urban densities as a pre-requisite for the sustainable planning of housing areas in European cities. The discussion on urban density will be focused on the urbanization processes in Europe, especially in relation to the differences witnessed in the re-urbanization phase of metropolitan areas between Post-communist countries and Western Europe.

In Death and Life of Great American Cities, Jane Jacobs stresses the importance of high population densities for American cities, while also making a clear distinction between high density - defined as population / hectare - and overcrowding expressed in number of persons / room (Schmitt 
/ cameră de locuit (Schmitt 1966). În ceea ce privește planificarea utilizării terenurilor, determinarea unor densități optime atinge două obiective: asigurarea furnizării bunurilor și serviciilor publice și asigurarea existenței terenurilor rezidențiale pentru toate categoriile de venit (Whitehead 2012).

\section{Avantajul densităților urbane ridicate}

Pentru a avea infrastructură și servicii publice eficiente, o densitate minimă este necesară, transportul public, spre exemplu, devenind viabil de la densități ale populației de 90-120 locuitori / hectar (Ekurhuleni Metropolitan Municipality 2005). Nu doar rețelele de transport public, ci și magazinele și școlile necesită densități de cel puțin 50 locuințe / hectar (Whitehead 2012). Mai mult, în timp ce zonele metropolitane mai dense sunt asociate unor viteze de deplasare mai mici, ele prezintă o proximitate mai mare între origine și destinație, fapt ce ameliorează sistemul de transport și accesibilitatea globală (Levine et al 2012).

Densitățile urbane mai ridicate sunt de asemenea necesare pentru asigurarea eficienței economice a proiectelor de infrastructură de apă-canal (Álvarez et al 2014), ducând, în același timp, la un consum global mai mic de energie - fapt ce se traduce, de fapt, printr-o eficiență energetică sporită (Güneralp et al 2017). Prin urmare, o dezvoltare compactă (ce implică, bineînțeles, densități urbane mai ridicate) oferă o eficiență mai mare în utilizarea serviciilor și infrastructurilor publice (California Planning Roundtable 2012).

"Densitatea mai ridicată este de asemenea mai eficientă în asigurarea unor comunități mixte, a integrării sociale și a siguranței" (Whitehead 2012,
1966). As far as land use planning is concerned, determining optimal densities serves two purposes: ensuring an adequate provision of public goods and services and ensuring adequate residential land for all income groups (Whitehead 2012).

\section{The advantages of high urban densities}

A minimum density is required in order to have efficient public infrastructure and services, with public transport becoming viable at population densities of 90-120 people / hectare (Ekurhuleni Metropolitan Municipality 2005). Not only public transport networks, but also shops and schools require densities of at least 50 dwellings / hectare (Whitehead 2012). Moreover, while denser metropolitan areas are associated with slower travel speeds, it determines greater origin-destination proximity which improves transportation outcomes and overall accessibility (Levine et al 2012).

Higher urban densities are also necessary for ensuring cost efficiency of water and sewage infrastructure projects (Álvarez et al 2014), while at the same time determining less overall urban energy use - which translates in much improved energy savings (Güneralp et al 2017). Consequently, a compact development (involving higher urban densities) offers greater efficiency in the use of public services and infrastructure (California Planning Roundtable 2012).

"Higher density is also more effective in generating mixed communities, social integration and safety" (Whitehead 2012, 10) and is also considered to be a 
10) și este considerată a fi un factor semnificativ pentru performanța economică a unui oraș (Ekurhuleni Metropolitan Municipality 2005).

Deși avantajele menționate anterior sunt dificil de combătut, urbaniștii ar trebui să țină cont și de problemele asociate cu o densitate excesivă: supraîncărcarea infrastructurii, supra-popularea, congestia sau poluarea aerului (Williams 2004).

O discuție despre densitatea urbană este imposibilă fără a ține cont de dezvoltarea modelelor de urbanizare din ultimul secol, precum și de importanța zonelor metropolitane în economia globală de astăzi. Următoarea secțiune încearcă să conecteze fazele urbanizării cu anumite variații în densitatea urbană globală, cu o privire mai atentă asupra cazului specific al țărilor post-comuniste.

\section{Modele de urbanizare. Cazul special al țărilor post-comuniste}

Mișcarea igienistă din a doua parte a secolului al XIXlea sublinia nevoia unor dezvoltări urbane mai verzi, în opoziție cu orașul aglomerat, nesănătos al revoluției industriale. La începutul secolului XX, urbaniștii au propus diferite modele pentru dezvoltarea noilor orașe, conectate cu centrele urbane majore prin căi ferate sau șosele și bazate pe densități mai mici - cel mai cunoscut exemplu fiind Orașul-grădină al lui Ebenezer Howard. În 1935, Frank Lloyd Wright definește conceptul orașului Broadacre, care consolidează în continuare modelul de locuințe cu densitate mai mică (fiecare gospodărie având un hectar de teren disponibil). În articolul său, Frank Lloyd Wright afirmă că autovehiculul este una dintre invențiile care contribuie deja la construcția orașelor Broadacre (Wright 1935). În Statele Unite ale Americii, significant factor for the economic performance of a city (Ekurhuleni Metropolitan Municipality 2005).

While the above-mentioned advantages are difficult to refute, planners should also take into account the problems associated with excessive densification: infrastructure overload, overcrowding, congestion or air pollution (Williams 2004).

Discussing about urban density is impossible without taking into account the development of urbanization patterns in the last century, as well as the importance of metropolitan areas in today's global economy. The following section attempts to link urbanization phases with variations in overall urban density, with a closer look on the specific case of post-communist countries.

\section{Urbanization patterns. The special case of post-communist countries}

The hygienist movement in the second part of the $19^{\text {th }}$ century advocated the need for greener city developments, in opposition to the crowded, unhealthy city of the industrial revolution. At the beginning of the $20^{\text {th }}$ century, urban planners proposed different models regarding the development of new cities, connected with major urban centres through railways or roads and based on lower densities - the most known example being Ebenezer Howard's Garden City. In 1935, Frank Lloyd Wright launches the Broadacre city concept, which further enhances the model of lower density housing (with each household having one acre of land available). In his article, Frank Lloyd Wright states that the motor car is one of the inventions already working in the building of Broadacres (Wright 1935). In the United States, the Broadacre 
Broadacre City a fost un argument pentru dezvoltarea suburbiilor (un model de dezvoltare puternic contestat astăzi - vezi Montgomery 2013). Acest model a fost apoi replicat la nivel global, de la orașele noi din Regatul Unit (anii 1950) la dezvoltările suburbane din țările post-comuniste în anii $1990-2000$.

Dezvoltarea zonelor metropolitane este un proces puternic legat de globalizare (Lefevre 2010) - se consideră, de altfel, că economia globală operează cel mai eficient într-un mediu metropolitan (Szirmai \& Fassman 2012). Noile activități economice dezvoltate în zonele metropolitane servesc adesea orașele principale, dar creează locuri de muncă și pentru locuitorii celorlalte localități din jur (Tang \& Xu 2008).

Extinderea terenurilor construite în zonele urbane se realizează adesea printr-o dezvoltare rezidențială necontrolată (Pătroescu et al 2011). În acest sens, dezvoltarea urbană poate fi caracterizată prin 4 faze de evoluție: urbanizare, suburbanizare, dezurbanizare și re-urbanizare, definite prin relațiile de creștere sau declin între centrul urban și zona peri-urbană (van den Berg et al 1982). Suburbanizarea este considerată a fi cel mai vizibil proces de schimbare metropolitană în perioada post-socialistă (Sýkora \& Stanilov 2014), România fiind de asemenea caracterizată printr-o fază de suburbanizare în ultimele decenii (Grigorescu et al 2012).

În cazul Europei, suburbanizarea este un proces ce determină inegalități socio-spațiale, cu clasele sociale mai dezavantajate adesea concentrate în suburbii (Szirmai 2011). În plus, impacturile de mediu negative ale dezvoltărilor de tip dispersie urbană, caracteristice inclusiv pentru țările post- city has been an argument for the further development of suburbs (a development model strongly criticized today - see Montgomery 2013). This model was afterwards globally replicated, from the 1950s UK's New Towns to the suburban developments in post-communist countries in the 1990s - 2000s.

The development of metropolitan areas is a process closely related to globalization (Lefevre 2010) - as the global economy is considered to operate most efficiently in a metropolitan environment (Szirmai \& Fassman 2012). The new economic activities developed in metropolitan areas usually serve the main cities, but create jobs for the settlements around as well (Tang \& Xu 2008).

The extension of built-up land in metropolitan areas is often made through uncontrolled residential development (Pătroescu et al 2011). In this regard, urban development can be characterized by four phases of evolution: urbanization, suburbanization, deurbanization and re-urbanization, defined by the growth vs. decline relationship between the urban centre and the peri-urban area (van den Berg et al 1982). Suburbanization is considered to be the most visible process of post-socialist metropolitan change (Sýkora \& Stanilov 2014), with Romania also being characterized by the suburbanization urban development phase in the last decades (Grigorescu et al 2012).

In Europe's case, suburbanization is a process which determines socio-spatial inequalities, with lower social classes increasingly concentrated in the suburbs (Szirmai 2011). In addition to this, the negative environmental impacts of urban sprawl development patterns, characteristic also for post- 
socialiste din Centrul și Estul Europei (Sýkora \& Stanilov 2014), au fost documentate pe larg în literatura științifică de specialitate (EEA 2006).

Deși acest articol nu se va focaliza pe aspectele sociale sau de mediu legate de densitatea urbană, este important de sintetizat faptul că densitățile mai ridicate, în forma dezvoltărilor de tip oraș-compact (opuse dezvoltărilor de tip dispersie urbană), contribuie decisiv la atingerea obiectivelor dezvoltării durabile (Williams 2004):

- Încurajarea unor mijloace de transport sustenabile;

- Utilizarea sustenabilă a terenurilor (asigurând conservarea zonelor rurale);

- Asocierea cu utilizări mixte, ce duc la diversitate, coeziune social și dezvoltare culturală;

- Viabilitate economică (costuri mai mici ale infrastructurii publice, densități ale populației suficiente pentru a susține serviciile locale).

Dezvoltarea suburbană în țările central-est europene își are originile în anii 1990, fiind legată de transformările în modelele de creștere urbană după căderea comunismului (Sýkora \& Stanilov 2014). Astfel, față de abordarea comunistă a urbanizării, bazată pe industrializare rapidă, dezvoltare egalitară, limitarea zonelor construite și dezvoltarea cartierelor de locuințe colective, se observă o schimbare bruscă determinată de trei factori principali, conduși de reformele timpurii din perioada post-socialistă (Stanilov \& Sýkora 2014):

- Privatizarea proprietății statului, inclusiv terenurile agricole apropiate de zonele urbane, fapt ce a determinat o piață funciară suburbană foarte activă; socialist Central and Eastern European (CEE) countries (Sýkora \& Stanilov 2014), have been widely documented in scientific literature (EEA 2006).

While this paper will not focus on social and environmental aspects related to urban density, it is important to synthesize that higher densities, in the form of compact-city development (as opposed to urban sprawl development), greatly contribute to reaching sustainability objectives (Williams 2004):

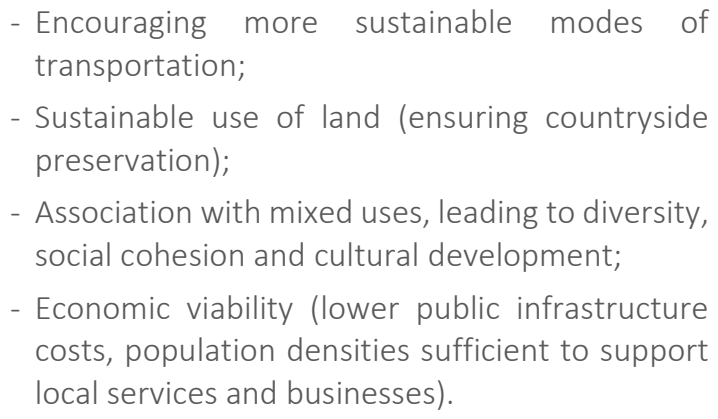

- Economic viability (lower public infrastructure costs, population densities sufficient to support local services and businesses).

Suburban development in CEE countries has its origins in the 1990s, being linked to dramatic transformations in urban growth patterns after the fall of communism (Sýkora \& Stanilov 2014). Consequently, the communist approach to urbanization, based on fast industrialisation, egalitarian development, containment of built-up areas and collective housing in high density residential areas (Elisei \& Pascariu 2012), was suddenly changed due to three main factors driven by early post-socialist reforms (Stanilov \& Sýkora 2014):

- The privatization of state assets, including agricultural land close to cities, which led to very active suburban land markets; 
- De-reglementarea activităților economice, inclusiv liberalizarea prețurilor și chiriilor și apariția unei piețe imobiliare rezidențiale independente;

- Descentralizarea puterii politice, autoritățile locale având dreptul de a reglementa dezvoltarea terenurilor fără constrângeri impuse de guvernele regionale sau naționale.

O mare parte din creșterea economică în țările postsocialiste a fost concentrată în zonele metropolitane majore, în special începând cu finalul anilor 1990 (Sýkora \& Stanilov 2014). Acest fapt a favorizat un urbanism condus de piața liberă, unitățile administrativ teritoriale mai mici din zona suburbană având un stil antreprenorial de management urban, favorizând adesea interesul investitorilor (fără a ține suficient cont de consecintele socio-spațiale sau de mediu) mai presus decât interesul public (Stanilov \& Sýkora 2014). Rezultatul a fost o dezvoltare urbană dispersată, caracterizată printr-un peisaj foarte fragmentat, adesea fără servicii și infrastructură de bază (Sýkora \& Stanilov 2014) și determinând astfel impacturi de mediu, sociale și economice negative pentru comunitățile locale (Cocheci 2014).

Orașele europene trec în acest moment printr-o fază de re-urbanizare, cu intensificarea urbană adesea asociată unor procese de gentrificare. Un exemplu elocvent sunt ariile metropolitane din Regatul Unit, unde procesul de re-urbanizare (creștere a populației mai mare în orașe decât în zonele periurbane ale acestora) este însoțit de schimbări în structura socială a orașelor și în dezvoltarea proiectelor imobiliare rezidențiale (Couch \& Fowles, 2019). Contribuie această abordare cu privire la densificare la orașe cu o calitate mai ridicată a
- Deregulation of economic activities, including the liberalization of prices and rents and the emergence of a private, independent real estate housing market;

- Decentralization of political power, with local authorities having the right to regulate land development without any constraints imposed by the national or regional governments.

A vast share of growth in post-socialist countries, especially beginning with the end of the 1990s, was concentrated in major metropolitan areas (Sýkora \& Stanilov 2014). This favoured a market-driven approach to urban planning, as smaller suburban municipalities adopted an entrepreneurial style of urban management, often favouring the investors' interests (with little regard for socio-spatial and environmental consequences) over those of the general public (Stanilov \& Sýkora 2014). The result was an urban sprawl development characterized by a highly fragmented landscape, often lacking basic services and infrastructure (Sýkora \& Stanilov, 2014) and thus determining significant environmental, social and economic negative impacts to local communities (Cocheci 2014).

European cities are currently undergoing a phase of re-urbanization, with urban intensification often associated with gentrification processes. The metropolitan areas in the United Kingdom are a good example in this regard, as the re-urbanization processes here (a greater rise in population in the cities than in the peri-urban areas) are linked with changes in the social structure of the city and in the real estate development of residential areas (Couch \& Fowles, 2019). Does this densification approach contribute to more liveable cities? And what is the 
locuirii? Și care este situație în regiunea metropolitană a Bucureștiului comparativ cu alte zone metropolitane europene?

\section{Metodologie}

În prima parte am descris contextul actual european, cu ajutorul bazei de date Eurostat.

Datele statistice disponibile se concretizează în patru direcții de analiză (Eurostat 2014):

- Modele de urbanizare și dezvoltare urbană în UE

- Distribuția spațială a dezvoltării urbane

- Creșterea și declinul populației urbane și a activității economice a acesteia

- Proiecții ale populației europene în perioada 2015-2050.

În a doua parte, am analizat situație existentă cu privire la densitate și locuire în regiunea București Ilfov (ce cuprinde municipiul București, capitala României, și județul Ilfov format din 40 de Unități Administrativ-Teritoriale, inclusiv opt orașe). Pentru simplificare, ne vom referi la această zonă de studiu ca fiind Regiunea Metropolitană București, considerând-o similară cu alte regiuni metropolitane din Europa (Greater London, Ile-de-France).

Pentru această zonă de studiu, următorii indicatori au fost analizați, pe baza datelor publice furnizate de către Institutul Național de Statistică (baza de date TEMPO online):

- Densitate: densitatea populației (locuitori / hectar) și densitatea locuințelor (număr de locuințe / hectar) între anii 2010 - 2014. Densitatea a fost calculată folosind doar suprafața zonelor construite (cu cel mai recent situation in the Bucharest metropolitan region compared to other European metropolitan areas?

\section{Methodology}

In the first part we used the Eurostat data base to describe the current European context.

The Eurostat data analysis reveals four main relevant topics (Eurostat 2014)

- Patterns of urban and city development in the EU

- Spatial distribution of urban developments

- The growth/decline of urban populations and their economic activity

- European Population projections for 2015-2050

In the second part, we analysed the current situation regarding density and housing issues in the București - Ilfov region (comprising the municipality of Bucharest, the capital city of Romania, and the county of Ilfov containing 40 Local Administrative Units, including eight towns). For further simplification, we will refer to this study area as the Bucharest Metropolitan Region, as we consider it similar to other metropolitan regions in Europe (see Greater London or Ile-de-France).

For this area, the following set of indicators was analysed, based on public data provided by the National Institute of Statistics (TEMPO online database):

- Density: population density (people / hectare) and dwelling density (number of dwellings / hectare) between the years 2010 - 2014. Density was computed using only the surface of built areas (with the most recent available year being 
an cu date disponibile fiind 2014). Cu toate acestea, în unele cazuri poate fi înșelător deoarece zonele construite cuprind, de exemplu, zone industriale.

- Dinamică: populație, număr de locuințe (2002 2018).

- Locuire: suprafața camerelor de locuit / persoană, dotări educaționale și sanitare (2002 2017).
2014). However, in some cases this might be misleading as built areas also comprise, for example, industrial areas.

- Dynamics: population, number of dwellings (2002 - 2018).

- Housing: residential surface / inhabitant, educational and sanitary amenities (2002 2017).

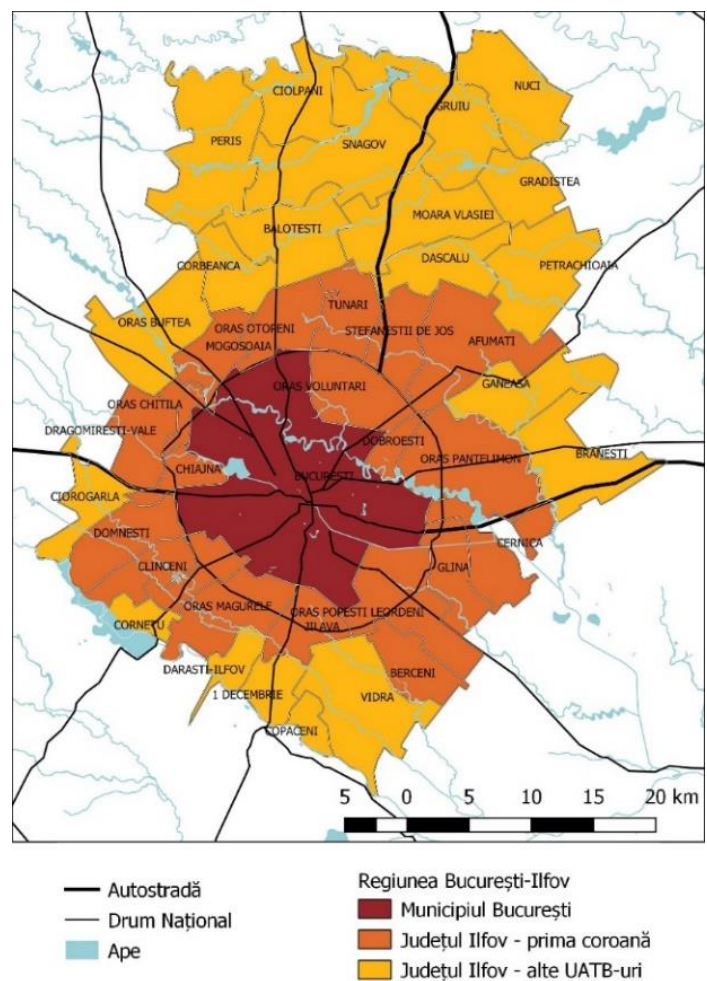

Fig. 1: Abordare metodologică - analiză București vs. Ilfov. Sursa: Autorii./ Methodological approach - Bucharest - Ilfov analysis. Source: Authors. 
Pentru a analiza mai bine diferențele generate de dezvoltarea suburbană post-1990, am diferențiat între prima coroană de localități din jurul Bucureștiului și restul județului Ilfov (vezi Fig. 1).

\section{Zone metropolitane din Europa}

În 2008, Națiunile Unite au estimat că peste 50\% din populația lumii trăiește în zone urbane, ceea ce a reprezentat atingerea unui prag istoric. Conform estimărilor Eurostat, în 2014 aproape trei sferturi din populația Uniunii Europene locuiește în orașe. Dinamica distribuției spațiale a acestor dezvoltări urbane variază însă enorm în cadrul țărilor membre UE. În cazul Olandei, atât densitatea populației, cât și procentul de utilizare a spațiului urban sunt ridicate. Prin comparație, procentul de ocupare a terenului și coeficienții de utilizare a acestuia sunt mult mai scăzuți în țările nordice și cele din Peninsula Iberică. (Eurostat 2014)

Creșterea populației din ultimele decenii și disponibilitatea limitată de dezvoltare a orașelor existente a rezultat în anularea limitei între urban și rural. În cele mai multe cazuri, tendința a fost de migrare a populației din interiorul ariei urbane spre suburbii și zone peri-urbane (zone hibrid, fragmentate, caracterizate de întrepătrunderea urbanului și ruralului), limitrofe ale regiunilor metropolitane existente. Procesul a fost încurajat de creșterea nivelului de independență motorie, îmbunătățirea sistemului de circulații și transport în comun, aspirații către o mai bună calitate a vieții și îmbunătățirea condițiilor de locuire față de oferta disponibilă în interiorul orașului.

Distribuția spațială a orașelor din țările europene
In order to better analyse the differences generated by suburban development after 1990, we differentiated between the first belt of Local Administrative Units around Bucharest and the rest of Ilfov county (see Fig. 1).

\section{European Metropolitan Areas}

In 2008, the United Nations estimated that over 50\% of the world's population lived in urban areas, which represented a historic threshold. According to Eurostat estimates, nearly three-quarters of the European Union population lives in cities in 2014. The dynamics of the spatial distribution of these urban developments vary enormously across EU countries. In the case of the Netherlands, both the population density and the percentage of use of urban space are high. By comparison, the percentage of land occupancy and its correlated indicators are much lower in the Nordic and Iberian Peninsula. (Eurostat 2014)

The population growth in recent decades and the limited possibility of development of existing cities resulted in the cancellation of the urban / rural boundary. In most cases, the trend has been to migrate the population from within the urban area to the suburbs and peri-urban areas (fragmented hybrid areas, characterized by the intersection of urban and rural), the outskirts of existing metropolitan areas. The process was encouraged by increased levels of motor independence, improved infrastructure and public transport system, aspirations towards better quality of life and better living conditions than the offer available within the city.

The spatial distribution of cities in European 
este strâns legată de geografia și istoria locului. Majoritatea acestora s-au dezvoltat pe vechi așezăminte situate adiacent unui curs de apă sau în zone costiere. Totuși, anumite orașe cresc, evoluează, pe când altele stagnează ori intră în declin: succesul unui oraș se datorează, în mare parte, nivelului de atractivitate ca mediu de viață, de muncă sau studiu.

Media densității populației în Uniunea Europeană este de 116.4 locuitori $/ \mathrm{km}^{2}$ (Eurostat, GEOSTAT Population Grid 2011). Din suprafața totală a teritoriilor componente, însă, doar 44\% (1,95 milioane $\mathrm{km}^{2}$ din 4,5 milioane $\mathrm{km}^{2}$ ) sunt arii locuite. În 10\% din aceste teritorii se concentrează trei sferturi (77.2\%) din totalul populației UE, astfel de poli (București, Madrid, Paris etc) ajungând la densități medii de 2400 locuitori/ km² , de peste 17 ori mai mult decât media uniunii.

În mod specific, în țările post-comuniste s-a resimțit un puternic efect psihologic al eliberării de limitările sistemului politic. Aici, suburbanizarea este și o consecință socio-culturală, a revoltei față de opresiunile regimului. Pătura socială cu venituri ce depășeau media a simțit nevoia de a-și alinia standardul de viață și statutul social la propriile repere, la noua libertate dobândită. Astfel, inclusiv încercând să nege valorile și restricțiile impuse politic, populația s-a orientat spre individualizarea proprietății și asumarea deplină a acesteia: mașina proprie poate fi utilizată liber, facilitând deplasări pe distanțe mai mari, fără dependența de sistemul de transport public; migrarea în afara orașului, la casă presupune totodată naveta zilnică pentru muncă și serviciile urbane ce se regăsesc în zona urbană. countries is closely related to the geography and the history of the place. Most of them have developed on old settlements located adjacent to a stream or coastal area. However, some cities are growing, evolving, while others are stagnating or declining: the success of a city is largely due to its attractiveness as a living, work or study environment.

The average population density in the European Union is 116.4 inhabitants / km² $^{2}$ (Eurostat GEOSTAT Population Grid 2011). Of the total area of the constituent territories, however, only 44\% (1.95 million $\mathrm{km} 2$ of 4.5 million $\mathrm{km} 2$ ) are inhabited areas. In $10 \%$ of these territories, three quarters (77.2\%) of the total EU population are concentrated, with such poles (Bucharest, Madrid, Paris etc.) reaching average densities of 2400 inhabitants / km2, more than 17 times higher than the Union average.

Specifically, a peculiar psychological effect of liberation from the limitations of the political system can be observed in the post-communist countries. Here, suburbanization is also a socio-cultural consequence, one of revolt against the oppression of the regime. The population with a higher than average income felt the need to align its standard of living and social status to its own bar, to the new acquired freedom. Thus, trying to deny the politically imposed values and restrictions, the population focused on the individualization of the property and its full responsibility: the privatelyowned car can be used freely, facilitating travel on greater distances without being dependent on the public transport system; the migration outside the city, to a single-family house implies commuting daily for work, but also for different urban services found in the city. 


\section{Regiunea metropolitană București - impactul dezvoltării suburbane}

Densitatea populației în cele mai multe Unități Administrativ-Teritoriale (inclusiv orașele PopeștiLeordeni, Voluntari, Măgurele) era de sub 30 locuitori / hectar în 2014, fără diferențe semnificative între prima coroană de localități și restul județului. În București, densitatea populației era de 135 locuitori / hectar. Densitatea scăzută a populației era reflectată și în calculul densității numărului de locuințe în 2014, cu cele mai multe UAT-uri (inclusiv orașe precum Otopeni, Măgurele sau Chitila) înregistrând valori de sub 10 locuințe / hectar, fără diferențe semnificative în județul Ilfov între prima coroană de UAT-uri din jurul Bucureștiului și celelalte UAT-uri (vezi Fig. 2). Prin urmare, toate Unitățile Administrativ-Teritoriale din județul Ilfov sunt caracterizate de densități scăzute, ceea ce sugerează o lipsă de eficiență în furnizarea infrastructurii și serviciilor publice. Următoarele concluzii pot fi extrase din analiza comparativă a dinamicii populației și a numărului de locuințe între 2002 și 2018 (toate cifrele rotunjite la o mie / la procent întreg).

Județul Ilfov a depășit Bucureștiul în ceea ce privește creșterea numărului de locuințe (+85.000 între 2002-2018 - sau +87\% - comparativ cu +82.000 în municipiul București - sau +10,5 \% - în același interval). Creșterea a fost mai semnificativă în prima coroană de localități (+71.000 sau + $127 \%)$, dar cum densitățile rămân scăzute se poate spune că la această creștere au contribuit în principal dezvoltările cu locuințe individuale izolate pe lot.

În același timp, rata de creștere a populației a fost considerabil mai scăzută decât rata de creștere a

\section{Bucharest metropolitan region - impact of suburban development}

Population density in most of the Local Administrative Units (including the towns of PopeștiLeordeni, Voluntari, Măgurele) was below 30 inhabitants / hectare in 2014, with no significant differences between the first belt and the rest of the county. In Bucharest, the population density was 135 inhabitants / hectare. The low populations densities were also reflected in the computation of housing densities in 2014, with most LAUs (including towns such as Otopeni, Măgurele or Chitila) registering values of under 10 dwellings / hectare, with no significant differences in Ilfov county between the first belt of LAUs around Bucharest and the other LAUs (see Fig. 2). Consequently, all Local Administrative Units in Ilfov county are characterized by low densities, which in turn suggests a lack of efficiency in the provision of infrastructure and public services. The following main findings could be extracted from the comparative analysis of the population and housing dynamics between 2002 and 2018 (all figures rounded to a thousand / a full percent).

Ilfov county has surpassed Bucharest as far as the growth in number of dwellings is concerned ( $+85,000$ between 2002-2018 - or $+87 \%$ - compared to $+82,000$ in Bucharest - or $+10,5 \%$ - in the same interval). The growth has been most significant in the first belt $(+71,000$ or $+127 \%)$, but as densities remain low one can argue that the growth was mainly reliant on low-density detached single-family housing development.

In the meantime, population growth rate was considerably lower than the number of dwellings 
numărului de locuințe $(-1,80$ \% în București și $+52 \%$ în județul Ilfov). Dintre cei 145.000 locuitori câștigați de județul Ilfov între 2002 și 2018, 121.000 erau localizați în prima coroană de localități. growth rate $(-1,80 \%$ in Bucharest and $+52 \%$ in Ilfov county). Of the 145,000 inhabitants gained by IIfov county between 2002 and 2018, 121,000 are located in the first belt.
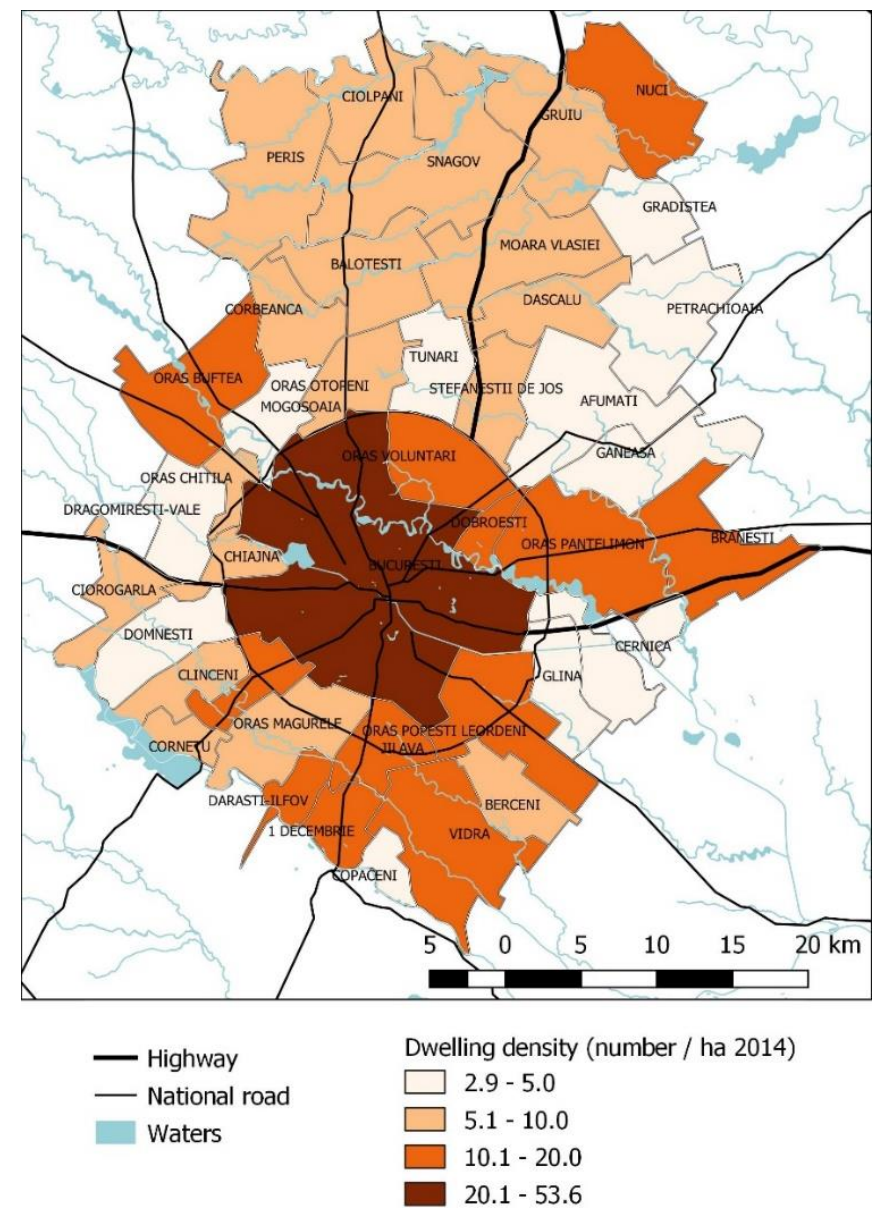

Fig. 2: Densitatea locuințelor în regiunea metropolitan București în 2014. Sursa: Autorii./ Density of dwellings in the Bucharest metropolitan region in 2014. Source: Authors. 
Diferența între rata mai joasă de creștere a populației și rata mai ridicată de creștere a numărului de locuințe este vizibilă atunci când se analizează suprafața camerelor de locuit pe locuitor, ce a înregistrat creșteri considerabile între 2002 și 2017: de la 15,57 la 29,55 mp / locuitor în Ilfov și de la 13,86 la 19,18 mp / locuitor în București.

Cu toate acestea, deși populația și numărul de locuințe a continuat să crească în județul IIfov, în special în prima coroană de Unități AdministrativTeritoriale din jurul Bucureștiului, serviciile publice nu au reușit să crească în același ritm. În timp ce în municipiul București numărul de cadre didactice / 1000 locuitori era 15,69 în anul 2017, în prima coroană, acolo unde s-a înregistrat cea mai mare parte din creșterea populației, valoarea era de doar 6,33 cadre didactice / 1000 locuitori. Valorile sunt foarte scăzute (sub 5 locuitori / 1000 locuitori) în orașe cu creșteri importante ale populației precum Popești-Leordeni, Bragadiru sau Pantelimon. În ceea ce privește dotările sanitare, datele statistice reflectă o dependență și mai mare a rezidenților județului Ilfov de serviciile publice localizate în București - doar orașele Buftea și Otopeni au peste un medic / 1000 locuitori.

În timp ce lipsa serviciilor publice în noile zone rezidențiale este de asemenea o slăbiciune ce provine din lipsa unor reglementări urbanistice clare privind dezvoltarea imobiliară privată, este clar că procesele de suburbanizare survenite în regiunea metropolitană București în ultimele trei decenii, bazate pe un model de dispersie urbană, cu densități joase, nu au considerat importanța densității urbane în asigurarea viabilității și eficienței investițiilor publice în infrastructura tehnică (apă, canalizare, alimentare cu gaze naturale), transport public sau
The difference between the lower population growth rate and the higher growth rate as far as the number of dwellings is concerned is visible when analysing the housing surface per inhabitant, which has registered a considerable growth between 2002 and 2017 - from 15.57 sqm to 29.55 sqm in Ilfov and from 13.86 to 19.18 sqm in Bucharest.

Nevertheless, while the population and number of dwellings has kept on growing in Ilfov, especially in the first belt of Local Administrative Units around Bucharest, the public services have not kept the same pace. While Bucharest registered in 2017 a number of 15.69 teachers / 1000 inhabitants, in the first belt, where most of the population growth was registered, the value was only 6.33 teachers / 1000 inhabitants. The values are considerably low (under 5 teachers / 1000 inhabitants) in towns with an important growth in population such as PopeștiLeordeni, Bragadiru and Pantelimon. As far as sanitary equipment is concerned, the data reflects an even greater dependence of Ilfov residents on the public services located in Bucharest - only the towns of Buftea and Otopeni have above one medical doctor / 1000 inhabitants.

While the lack of public services in new residential areas is also a weakness stemming from the lack of clear planning regulations regarding private residential development, it is also clear that the suburbanization process in the Bucharest metropolitan region in the last three decades, based on an urban sprawl, low-density model, did not consider the importance of urban density in ensuring the viability and efficiency of public investment in technical infrastructure (water, sewage, gas), public transport or other public 
alte dotări și servicii publice (educație, sănătate, cultură). Noile dezvoltări rezidențiale din zona periurbană a Bucureștiului au răspuns unei nevoi privind cererea de locuințe, precum și dorinței populației de a se muta în locuințe individuale pe lot. Cu toate acestea, avizând aceste proiecte imobiliare fără a pune condiții dezvoltatorilor, autoritățile publice locale au ignorat faptul că densitățile mici rezultate vor face foarte costisitoare lucrările publice de infrastructură necesare asigurării unei calități ridicate a locuirii.

\section{Concluzii}

Analiza realizată la nivelul regiunii metropolitane Bucureşti-Ilfov a ilustrat modul în care o densitate scăzută a populației, respectiv a numărului de locuințe contribuie la lipsa unor dotări şi servicii publice din teritoriile afectate de procesul de suburbanizare. În acest caz, trebuie gândite politici de intensificare, atât prin utilizarea terenurilor abandonate din Bucureşti (fostele platforme industriale), cât şi prin diversificarea activităților economice, crearea de noi locuri de muncă şi zone rezidențiale mai dense în oraşele din jurul Bucureştiului. Optimizarea consumului de spațiu devine o nevoie a orașelor în vederea asigurării unei dezvoltări sustenabile și a ameliorării calității locuirii, iar în cazul regiunii metropolitane București există resurse de teren în acest sens: terenuri virane, platforme industriale și întreprinderi agricole abandonate sau zone unde țesutul urban existent permite densificarea.

O abordare compactă presupune, așadar, un consum eficient de spațiu corelat în mod direct cu o densitate ridicată. Concluzia este susținută de studii, de analize și - mai ales - de experiența orașelor ce services (educational, sanitary, cultural). The new residential developments in Bucharest's peri-urban area answered a need regarding housing demand, as well as the population's desire to move to singlefamily houses. Nevertheless, by approving these real estate developments without imposing conditions to the developers, the local public authorities have ignored the fact that the resulting lower densities would make public infrastructure works which are necessary for assuring a high quality of living very expensive.

\section{Conclusions}

The analysis carried out at Bucharest-Ilfov metropolitan region illustrated how low population and dwelling density contribute to the lack of public facilities and services in the territories affected by the suburbanization process. In this case, intensification policies have to be designed, both by encouraging the use of abandoned lands in Bucharest (former industrial platforms) and by diversifying economic activities, creating new jobs and denser residential areas in the cities around Bucharest. Optimizing space consumption becomes a necessity for cities in order to ensure a sustainable development and improve the quality of living, and in the case of Bucharest metropolitan region the space resource still exists: abandoned land, derelict industrial and agricultural platforms or areas where the existing urban tissue allows further densification.

A compact approach thus implies an efficient consumption of space directly correlated with high density. The conclusion is supported by studies, analyses and - above all - by the experience of cities 
au ales să caute soluții pentru creșterea calității vieții urbane, pentru optimizarea modului de utilizare a resurselor și serviciilor urbane, spre potențarea unui model de interacțiune fluidă a consumatorului de spațiu cu orașul său. Totuși, densitatea ridicată nu este un concept absolut, ci unul relativ; densitățile variază considerabil de la o țară la alta și de la un oraș la altul, iar ceea ce e considerat un indice ridicat al densității într-o țară, ar putea să nu pară la fel de mare în alta. Atingerea unui nivel optim al densificării în orașele existente se poate realiza doar printr-un amplu proces de intensificare - densificare specifică, planificată (Jenks 2000). Se pot cuantifica, așadar, parametri specifici de dezvoltare stabilitate, sănătate, cultură, mediu, educație și infrastructură - pentru o bună eficientizare a spațiului urban, parametri ce descriu atributele hard ale calității vieții urbane (The Global Liveability Index 2018). Rămân de introdus în discuție parametri soft, cei ce dau personalitate, vitalitate și ambianță orașului; de definit relația dintre intensitate, bucurie și tehnologie urbană: experiența spațiului public contemporan are loc între real și virtual, la limita între spațiul fizic și cel informațional (Enache \& Floroiu 2018). O posibilă direcție de aprofundare a studiului vizează analiza evoluției organice a sistemului determinat de elementele soft și cele hard ale mediului urban, spre o bună înțelegere a modificărilor modului de funcționare a organismului urban sub presiunea tehnologiilor emergente, a instrumentelor de monitorizare și optimizare digitală a mediului urban. that have chosen to look for solutions to increase the quality of urban life, to optimize the use of urban resources and services, to foster a model of fluid interaction of the space consumer with his city. However, high density is not an absolute concept, but a relative concept; density varies considerably from one country to another and from one city to another, and what is considered a high indication of density in a country may not seem as big in another. Achieving an optimal level of densification in existing cities can only be achieved through a large, intense, densified, planned, intensification process. (Jenks 2000). It is therefore possible to quantify specific development parameters - stability, health, culture, environment, education and infrastructure - for a good efficiency of urban space, parameters describing the hard attributes of the liveability (The Global Liveability Index 2018). It remains to introduce soft parameters, those who give the personality, vitality and ambience of the city; to define the relationship between urban intensity, joy and technology: the entire existence of the contemporary society takes place between real and virtual, between physical space and informational space (Enache \& Floroiu 2018). A possible direction of thoroughgoing study involves the analysis of the organic evolution of the system determined by the soft and hard elements of the urban environment, for a better understanding of the changes in the urban organism's functioning under the pressure of emerging technologies, monitoring instruments and digital optimization of the urban environment. 


\section{Referinţe/ References}

Álvarez, I. C., Prieto, Á. M., \& Zofío, J. L. (2014). Cost efficiency, urban patterns and population density when providing public infrastructure: A stochastic frontier approach. European Planning Studies, 22(6), pp. 1235-1258.

California Planning Roundtable. (2012). Myths and facts about affordable \& high density housing. California Department of Housing \& Community Development, http://www.hcd.ca.gov/community-development/communityacceptance/index/docs/mythsnfacts.pdf consultat la data de 18 iulie 2019.

Cocheci M. (2014). Environmental Impact Assessment of Urban Sprawl in the Brasov Metropolitan Area. Urbanism. Arhitectura. Constructii 5(2), pp. 21-37

Couch, C., \& Fowles, S. (2019). Metropolitan Planning and the Phenomenon of Reurbanisation: The Example of Liverpool. Planning Practice \& Research, 34(2), 184-205.

Ekurhuleni Metropolitan Municipality (2005). Guideline document for higher density residential development. Housing Department.

European Environmental Agency (EEA). (2006). Urban sprawl in Europe - The ignored challenge. EEA Report No. 10/2006.

Eurostat, statistics explained

https://ec.europa.eu/eurostat/statistics-

explained/index.php/Urban_Europe_\%E2\%80\%94_statistics_on_cities,_towns_and_suburbs_\%E2\%80\%94_patterns_of _urban_and_city_developments\#Patterns_of_urban_and_city_developments_in_the_EU consultat la data de 20 iulie 2019

Enache, C; Floroiu, I. (2018) Selfie-fying the Landscape. Space Awareness through Social Media. Logos Universality Mentality Education Novelty: Philosophy \& Humanistic Sciences, [S.I.], v. 6, n. 2, p. 57-62, jan. 2019. ISSN 2501-0409.

http://lumenpublishing.com/journals/index.php/lumenphs/article/view/1224 consultat la date de 10 iulie 2019

Grigorescu I., Mitrică B., Kucsicsa G., Popovici E.A., Dumitraşcu M., Cuculici R. (2012). Post-communist land use changes related to urban sprawl in the Romanian Metropolitan Areas, Journal of Studies and Research in Human Geography 6(1), pp. 35-46.

Güneralp, B., Zhou, Y., Ürge-Vorsatz, D., Gupta, M., Yu, S., Patel, P. L., ... \& Seto, K. C. (2017). Global scenarios of urban density and its impacts on building energy use through 2050. Proceedings of the National Academy of Sciences, 114(34), pp. 8945-8950.

Lefèvre C. (2010). The improbable metropolis: decentralization, local democracy and metropolitan areas in the Western World, Analise Social, vol. XLV (197), 2010, pp. 623-37.

Levine, J., Grengs, J., Shen, Q., \& Shen, Q. (2012). Does accessibility require density or speed? A comparison of fast versus close in getting where you want to go in US metropolitan regions. Journal of the American Planning Association, 78(2), pp. 157-172.

Montgomery, C. (2013). Happy city: Transforming our lives through urban design. Macmillan. 
Pătroescu M., Niţă M.R., lojă C., Vânău G., lojă A. (2011), Land Use Change in the Bucharest Metropolitan Area and its Impacts on the Quality of the Environment in Residential Developments, Forum geografic. Studii şi cercetări de geografie şi protecţia mediului, 10(1), pp. 177-186.

Schmitt, R. C. (1966). Density, health, and social disorganization. Journal of the American Institute of Planners, 32(1), pp. 38-40.

Stanilov K, Sýkora L. (2014). Managing Suburbanization in Postsocialist Europe. In L. Sýkora, K. Stanilov (Eds.), Confronting Suburbanization. Urban Decentralization in Postsocialist Central and Eastern Europe (pp. 296-320). Wiley Blackwell.

Sýkora L., Stanilov K. (2014). The Challenge of Postsocialist Suburbanization. In L. Sýkora, K. Stanilov (Eds.), Confronting Suburbanization. Urban Decentralization in Postsocialist Central and Eastern Europe (pp. 1-25). Wiley Blackwell.

Szirmai V. (2011), Urban Sprawl in Europe: An Introduction. In V. Szirmai (Ed.), Urban Sprawl in Europe. Similarities or differences? (pp. 15-44), Budapest: AULA Kiado, Budapest.

Szirmai V., Fassmann H. (2012). Metropolitan Regions in Europe: An Introduction. In V. Szirmai, H. Fassmann (Eds.), Metropolitan Regions in Europe (pp. 11-18), Budapest - Vienna: Austrian-Hungarian Action Fund.

Tang Y., Xu J. (2008). Regional Governance of the Capital Metropolitan Region: A Comparative Study of BerlinBrandenburg and Beijing, 44th ISOCARP Congress 2008.

The Global liveability index 2018,

https://pages.eiu.com/rs/753-RIQ-438/images/The_Global_Liveability_Index_2018.pdf consultat la 20 iulie 2018

Van den Berg L., Drewett R., Klaasen L. H., Rossi A., \& Vijverberg C. H. (1982). Urban Europe: A study of growth and decline. Elsevier.

Whitehead, C. (2012). The density debate: a personal view. London: London School of Economics and Political Science, Geography and Environment.

Williams, K. (2004). Can urban intensification contribute to sustainable cities? An international perspective. City Matters: Official Electronic Journal of Urbanicity.

Wright, F. L. (1935). Broadacre City: A new community plan. Architectural Record, 77(4), pp. 243-254. 